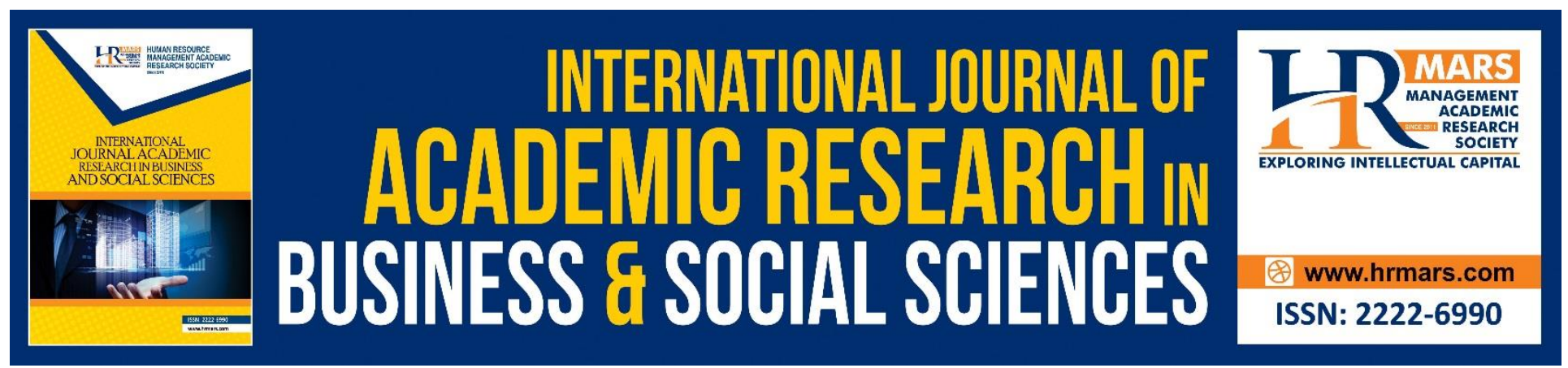

\title{
A Survey on the Culture of Online Shaming: A Malaysian Experience
}

Anida Mahmood, Haswira Nor Mohamad Hashim, Fazlin Mohamed Zain, Nurul Shuhada Suhaimi, Nur Asma Yahya

To Link this Article: http://dx.doi.org/10.6007/IJARBSS/v8-i10/5270

DOI: $10.6007 /$ IJARBSS/v8-i10/5270

Received: 02 Sept 2018, Revised: 17 Oct 2018, Accepted: 26 Oct 2018

Published Online: 30 October 2018

In-Text Citation: (Mahmood, Hashim, Zain, Suhaimi, \& Yahya, 2018)

To Cite this Article: Mahmood, A., Hashim, H. N. M., Zain, F. M., Suhaimi, N. S., \& Yahya, N. A. (2018). A Survey on the Culture of Online Shaming: A Malaysian Experience. International Journal of Academic Research in Business and Social Sciences, 8(10), 1125-1134.

\section{Copyright: (c) 2018 The Author(s)}

Published by Human Resource Management Academic Research Society (www.hrmars.com)

This article is published under the Creative Commons Attribution (CC BY 4.0) license. Anyone may reproduce, distribute, translate and create derivative works of this article (for both commercial and non-commercial purposes), subject to full attribution to the original publication and authors. The full terms of this license may be seen at: http://creativecommons.org/licences/by/4.0/legalcode

$$
\text { Vol. 8, No. 10, 2018, Pg. } 1125 \text { - } 1134
$$

Full Terms \& Conditions of access and use can be found at http://hrmars.com/index.php/pages/detail/publication-ethics 


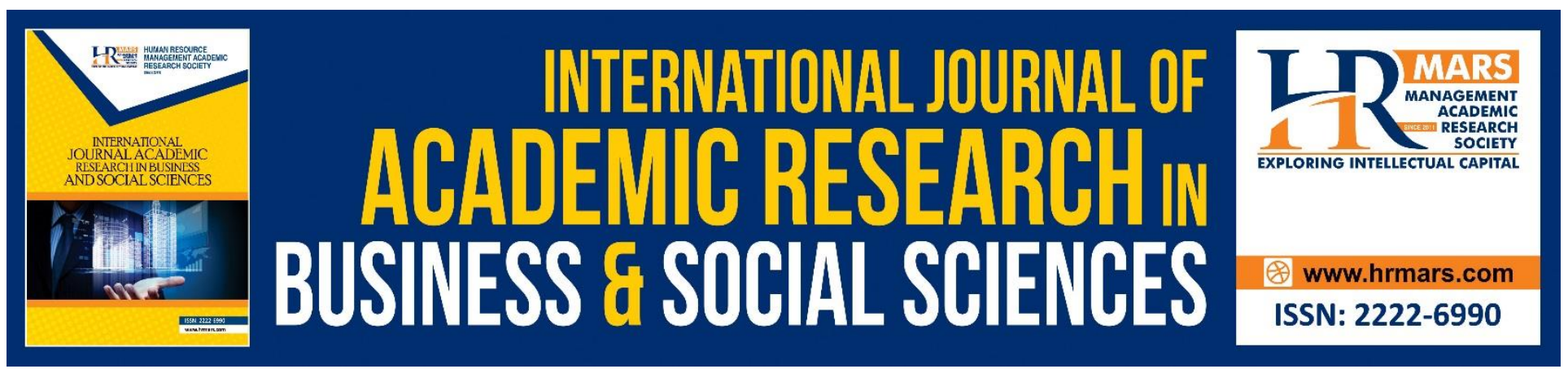

\title{
A Survey on the Culture of Online Shaming: A Malaysian Experience
}

\author{
Anida Mahmood*, Haswira Nor Mohamad Hashim, Fazlin Mohamed \\ Zain, Nurul Shuhada Suhaimi, Nur Asma Yahya \\ *Corresponding Author Email: anida131@salam.uitm.edu.my \\ Faculty of Law, Universiti Teknologi MARA, Selangor, Malaysia
}

\begin{abstract}
This study investigates the culture of online shaming in Malaysia. A survey amongst 320 UiTM law students was conducted using a five-point Likert scale survey questionnaire. A cross-sectional data was collected from 320 respondents. The survey finding indicates that online shaming postings are commonly found in social media application like Whatsapp, Instagram, Youtube, Facebook and Twitter. The survey finding also indicates that the most common behaviors associated with online shaming are sexism, racism or religious bigotry. Based on the findings, this paper concludes that the culture of online shaming in Malaysia is worrying and leads to abuse. The findings of the survey help to provide a beneficial input to the government, legislature and the public on the culture of online shaming in Malaysia, and the legal consequences of online shaming. This study urges for an awareness campaign to be undertaken at institution of higher learning and schools with emphasizes on the legal implications of online shaming arising from section 114A of the Evidence Act 1950 (presumption of online publication), section 211 of the Malaysian Communications and Multimedia Act 1998 (prohibition of online publication of false, annoying and threatening materials), Sedition Act 1948, Official Secrets Act 1972 and Data Protection Act 2010.
\end{abstract}

Keywords: Online Shaming, Culture, Students, Awareness, Legal Implication

\section{INTRODUCTION}

\section{Social Media and Online Shaming}

This study surveys the culture of online shaming in Malaysia. Online shaming frequently involves the publication of private information of a person on the internet (called doxing) to intimidate the person. Other than doxing, online shaming includes teen-shaming, slut-shaming, revenge porn, negative reviews and 'name \& shame' commonly used by the government to punish publicise tax evasion, environmental violations and minor crimes like littering (Carson, 2015). 
Online shaming also targets socially undesirable behaviours such as unsafe driving and bad parking among members of society (Mei Lin and Lau, 2015). It is also used to shame social media users who sent impolite, aggressive or insulting text messages (Allen, 2014). Among Malaysian Muslims, 'hijabshaming' is among the most common type of online shaming (Nurulsyahirah, 2015).

Incidents of online shaming are reported to be on the rise. Online shaming is largely enforced through social media applications, open forums, online news portals and blogs (Klonick, 2015). While social media enables online sharing of information, it also subjects to abuse. Online shaming is classified as a form of cyber bullying and cyber harassment. (Fagbenle, 2013), (Poole, 2013) and (Dewey, 2015). Online shaming emerged from the internet community response to the anti-social behaviours that may not necessarily require police action (Ho, 2015). The internet provides an avenue for enforcement of customs, values and behaviours and empowers the public to act upon any violation or to right injustices by publishing them online with the intention of shaming the offenders (Klonick, 2015).

Due to its widespread use and popularity, online shaming has fast become an important part of a new type of surveillance known as 'sousveillance' i.e. watch from below, where the practice of surveillance is inversed (Mann, Nolan and Wellman, 2003). In the context of online shaming, the surveillance is conducted by the online community and not by the authority. Judging by its objectives and functions, online shaming is both an act of internet vigilantism which is a mode of informal regulation within online communities as well as a form of cyber social control (Wehmhoener (2010), Phillips and Miltner (2012).

\section{Online Shaming as an Instrument of Social Control}

The prevalence culture of online shaming signifies the exploitation of shaming as an instrument of social control. The aim of online shaming is to punish real or perceived violation of a social norm (Klonick, 2015). Online shaming becomes an avenue for those who are upset or offended to impose some discipline (Ho, 2015). In addition, online shaming also targets socially undesirable behaviours such as unsafe driving and bad parking among members of society, to shame social media users who send impolite, aggressive or insulting text messages (Allen, 2014). Thus, it is evident that online shaming has been accepted as one of the instruments of social control.

Online shaming is aimed at addressing transgressions of norms and other social values which is a subjective judgment by large and does not rely on laws to indicate when an offence deserves a punishment. Online shaming in Malaysia is still classified as informal sanction as currently it is not part of a government endorsed shaming sanction like imprisonment or community service. Compared to formal sanction, what amounts to infringements and non-compliance behaviors or social norms that result online shaming vary and uncertain between societies. While online shaming serves as a court of public opinion, it can condemn a perceived wrongdoer and impose real life consequences. It has the power to shape public perception and impact lives, for better or worse.

According to the past literature, online shaming opens to abuse as there is no law to regulate the practice. Skoric (2010), Schulten (2015) and Cheung (2012) state that due to lack of procedure, online shaming can be abused by the netizens which can lead to humiliation. Goldman (2015) discusses on negative implications of using online shaming as an instrument of social control. In contrast, Wehmhoener (2010), treats online shaming as a form of internet vigilantism. Kaplan (2015) regards 
online shaming as a modality for justice and equality. Further, Dewey (2015) states that online shaming helps the vulnerable group to gain attention.

Online shaming has been credited by Phlips and Milner (2012) as an informal legal sanction in the absence of a meaningful legal solution and dissatisfaction of the formal sanction. Skoric (2010) and Massaro (1997) studies found that the effectiveness of online shaming as a deterrent is closely related with the individuals' characteristic and the community. Hence it is pertinent to survey the culture of online shaming in Malaysia. Surveying the culture of online shaming will benefit the society and the policy makers in dealing with online shaming in Malaysia. Appropriate measures can be introduced to curb the widespread of online shaming in Malaysia.

\section{METHOD}

The study is designed as a descriptive study which employs quantitative research method involving survey. A self-developed survey questionnaire was used as instrument for data collection. The survey questionnaire is divided into five separate sections. The first section (Part A) was designed with the purpose of obtaining the demographic information of the respondents by using nominal data. The remaining sections of the survey (Part $B$ - Part $E$ ) were designed to meet the four objectives of this research. Each section contains a 10 -item statement, based on five-point Likert scale ranging from the lowest to the highest. The statements were formulated from a number of sources including the literature review and personal experiences. A small-scale pilot study involving 10 respondents was conducted to ensure the validity and reliability of the survey instruments.

The population for the survey is 1780 students who have enrolled as bachelor and post-graduate students at UiTM Law Faculty as at 30th September 2016. Due to budget and time constraints, the survey is limited to UiTM law students. While law students only made up slightly over $10 \%$ of 15,000 students in UiTM Shah Alam, they are the best population for this research since they have better understanding of the aim and function of online shaming as an instrument of social control.

Sample size is determined by using Krejcie and Morgan table (1970) whereby for finite population of 1800 , the required sample size is 317 with $95 \%$ confidence level and margin of error at 0.05 . To avoid sample selection bias, a stratified sampling is used whereby the relevant stratum is the student's academic level. The layer size of each academic level is 1387 for Bachelor, 76 for Advance Diploma, 289 for Master and 23 for Doctorate. Based on proportionate stratified sampling equation, the sampling fractions are 247 from Bachelor students, 13 from Advance Diploma students, 289 from Master students and 23 from Doctorate students.

A self-administered survey questionnaire was distributed by hand using random sampling techniques to 320 respondents between 1 October 2016 until 1 April 2017. The survey questionnaires duly completed by the respondents were collected on the same day by the researchers themselves. The respondents comprised of $71.9 \%$ females and $27.2 \%$ males, with $87.8 \%$ are single and the remaining respondents are either married or divorced. Majority of the respondents are Malay (94.1\%), followed by the native of Sabah and Sarawak (6\%), with $96.3 \%$ of them are Muslim. Data analysis was 
INTERNATIONAL JOURNAL OF ACADEMIC RESEARCH IN BUSINESS AND SOCIAL SCIENCES

Vol. 8, No. 10, Oct. 2018, E-ISSN: 2222-6990 ㄷ 2018 HRMARS

conducted using SPSS v. 24, whereby the survey data was analyzed using both descriptive and statistical data analysis.

FINDINGS

TABLE 1: Type of offences/anti-social behaviours commonly $\mathrm{read} / \mathrm{posted} / \mathrm{share} / \mathrm{liked} / \mathrm{commented}$ online

\begin{tabular}{|c|c|c|c|c|c|c|c|c|c|c|c|c|c|c|c|c|c|c|c|}
\hline & $\begin{array}{l}\text { Type of } \\
\text { offences/anti- } \\
\text { social } \\
\text { behaviours }\end{array}$ & & $\begin{array}{l}\text { Child } \\
\text { abuse / } \\
\text { Domesti } \\
\text { c } \\
\text { violence }\end{array}$ & $\begin{array}{l}\text { Poor } \\
\text { service/ } \\
\text { product }\end{array}$ & $\begin{array}{l}\text { Insensiti } \\
\text { vityignor } \\
\text { ance/inc } \\
\text { onsidera } \\
\text { te }\end{array}$ & $\begin{array}{l}\text { Corrupt } \\
\text { acts/ } \\
\text { abuse of } \\
\text { power }\end{array}$ & $\begin{array}{l}\text { Bad/illegal } \\
\text { parking }\end{array}$ & $\begin{array}{l}\text { Reckless/ } \\
\text { dangero } \\
\text { us } \\
\text { driving }\end{array}$ & $\begin{array}{l}\text { Crude } \\
\text { display } \\
\text { of } \\
\text { privilege }\end{array}$ & $\begin{array}{l}\text { Fighting/ } \\
\text { bullying }\end{array}$ & $\begin{array}{l}\text { Litterin } \\
\text { g/spitti } \\
\text { ng/smo } \\
\text { king }\end{array}$ & $\begin{array}{l}\text { Degradin } \\
\text { g/insultin } \\
\mathrm{g} \text { text } \\
\text { message } \\
\mathrm{s}\end{array}$ & $\begin{array}{l}\text { limpolit } \\
\text { e/ } \\
\text { rude/ } \\
\text { aggressi } \\
\text { ve } \\
\text { behavio } \\
\text { ur }\end{array}$ & $\begin{array}{l}\text { Paedho } \\
\text { pile }\end{array}$ & $\begin{array}{l}\text { Cheating/ } \\
\text { pick } \\
\text { pocketing } \\
\text { /stealing }\end{array}$ & $\begin{array}{l}\text { Sexism/raci } \\
\text { sm/religiou } \\
\text { s bigotry }\end{array}$ & $\begin{array}{l}\text { Unpatriotic } \\
\text { act }\end{array}$ & Others & $\begin{array}{l}\text { Respod } \\
\text { ent's } \\
\text { Code } \\
\end{array}$ \\
\hline \multirow[t]{2}{*}{$\mathrm{N}$} & & Valid & 320 & 320 & 320 & 320 & 320 & 320 & 320 & 320 & 320 & 320 & 320 & 320 & 320 & 320 & 320 & 320 & 320 \\
\hline & & $\begin{array}{l}\text { Missi } \\
\text { ng }\end{array}$ & & 0 & 0 & 0 & 0 & 0 & 0 & 0 & 0 & 0 & 0 & 0 & 0 & 0 & 0 & 0 & 0 \\
\hline Sum & & & 215 & 192 & 197 & 208 & 92 & 140 & 67 & 200 & 77 & 169 & 224 & 132 & 134 & 232 & 93 & 23 & 51360 \\
\hline
\end{tabular}

Table 1 reports 16 categories of offences or anti-social behaviours that are commonly read, post, share, like or commented by the respondents through social media. There are 8 categories of offences/anti-social behaviors that record the response rate above $50 \%$ among the respondents. Sexim, racism. religious and bigotry act records the highest response rate with 232 or $72.5 \%$ of the respondents admitted having read, post, share, like or commented. Second highest response rate is child abuse and domestic violence with 215 or $67.2 \%$ respondents. Crude display of privilege and other acts record the lowest response rate among respondents which are 92 (21\%) and $23(7.20 \%)$ respectively. Other offences that record low response rate are littering, spitting and smoking (77/24\%), bad and illegal parking (92/28.75) and unpatriotic act (93/29\%).

TABLE 2: Personal experience of the respondents in posting or being shamed online

\begin{tabular}{llr|r|r|r} 
& & & & \multicolumn{2}{c}{$\begin{array}{c}\text { Cumulative } \\
\text { Percent }\end{array}$} \\
\hline Valid & Frequency & Percent & Valid Percent & .9 \\
\cline { 2 - 6 } & Yes & 3 & .9 & .9 & 12.8 \\
\cline { 2 - 7 } & Never & 209 & 11.9 & 11.9 & 78.1 \\
\hline Not sure & 70 & 21.9 & 65.3 & 21.9 & 100.0 \\
\hline Total & 320 & 100.0 & 100.0 & \\
\hline
\end{tabular}

Table 2.1: Have you ever made shaming posting?

Table 2.1 reports the respondents' personal experience in making online shaming posting. From the survey, it is found that $38(11.9 \%)$ respondents admitted to have made shaming posting online. In contrast, 209 (65.3\%) respondents denied having ever made shaming posting online. There are 70 (21.9\%) respondents who are unsure whether they have ever made shaming posting. 
INTERNATIONAL JOURNAL OF ACADEMIC RESEARCH IN BUSINESS AND SOCIAL SCIENCES

Vol. 8, No. 10, Oct. 2018, E-ISSN: 222 2-6990 @ 2018 HRMARS

\begin{tabular}{ll|r|r|r|r} 
& & & & \multicolumn{2}{c}{$\begin{array}{c}\text { Cumulative } \\
\text { Percent }\end{array}$} \\
\hline Valid & Frequency & Percent & Valid Percent & 1.6 \\
\cline { 2 - 6 } & Yes & 5 & 1.6 & 1.6 & 22.5 \\
\cline { 2 - 6 } & 67 & 20.9 & 20.9 & 73.1 \\
\cline { 2 - 6 } & Never & 162 & 50.6 & 50.6 & 100.0 \\
\hline Not sure & 86 & 26.9 & 26.9 & \\
\hline
\end{tabular}

Table 2.2: Have you ever been shamed online?

Table 2.2 reports the respondents' personal experience of being shamed online. It is found that 162 respondents $(50.6 \%)$ had never been shamed online, compared to 67 respondents $(20.9 \%)$ admitted to have the personal experience of being shamed online. There are 86 respondents and $11.9 \%$ (38 respondents) who are unsure whether they have ever been shamed online.

\begin{tabular}{|c|c|c|c|c|c|}
\hline & & Frequency & Percent & $\begin{array}{c}\text { Valid } \\
\text { Percent }\end{array}$ & $\begin{array}{c}\text { Cumulative } \\
\text { Percent }\end{array}$ \\
\hline \multirow[t]{5}{*}{ Valid } & 0 & 4 & 1.3 & 1.3 & 1.3 \\
\hline & Yes & 97 & 30.3 & 30.3 & 31.6 \\
\hline & Never & 148 & 46.3 & 46.3 & 77.8 \\
\hline & Not sure & 71 & 22.2 & 22.2 & 100.0 \\
\hline & Total & 320 & 100.0 & 100.0 & \\
\hline
\end{tabular}

Table 2.3: Have you ever like/share/comment shaming posting?

Table 2.3 reports the respondents' answer to a survey whether they have ever like, share or comment shaming posting in social media. Based on the response given, 97 (30.3\%) respondents have liked, shared or commented shaming posting prior to the survey. However, $148(46.3 \%)$ respondents answered that they never like, share or comment shaming posting. 71 (22.2\%) respondents answered that they are not sure whether they have ever like, share or comment shaming posting.

Table 3: Online social media application commonly associated with online shaming

\begin{tabular}{|c|c|c|c|c|c|c|c|c|}
\hline & & Social & Social & Social & & & & \\
\hline & & media & media & media & & & & \\
\hline \multicolumn{2}{|r|}{ Social media } & application & application & application & Social media & Social media & Social medi & \\
\hline \multicolumn{2}{|r|}{ application } & commonly & commonly & commonly & application & application & applicatio & \\
\hline Respodent's & commonly & logged-in: & logged-in: & logged-in: & commonly & commonly & \multicolumn{2}{|l|}{ commonly } \\
\hline Code & logged-in: facebook & instagram & twitter & googleplus & logged-in:youtube & logged-in:telegram & \multicolumn{2}{|l|}{ logged-in:whatsapp } \\
\hline \multicolumn{2}{|r|}{ Sum } & Sum & Sum & Sum & Sum & Sum & \multicolumn{2}{|c|}{ Sum } \\
\hline \multicolumn{2}{|l|}{ Grand Total } & & & & & & & \\
\hline 320 & 187 & 236 & 182 & 104 & 204 & 37 & 30 & 05 \\
\hline
\end{tabular}


Table 3 reports the online social media application commonly associated with online shaming. There are 7 social media applications listed in the survey and the respondents are allowed to choose as many online social media as they like. The highest number of respondents (236/73.75\%) answered that Whatsapp is the social media application commonly associated with online shaming. Besides Whatsapp, 3 other social media applications i.e. Youtube, Facebook and Twitter record the response rates above $50 \%$ among the respondents as online social media application commonly associated with online shaming. The lowest number of response rate among the respondent for this category is Telegram application, which only records 37 (11.6\%) response rate.

Table 4: The Online Media platform where online shaming postings are commonly found

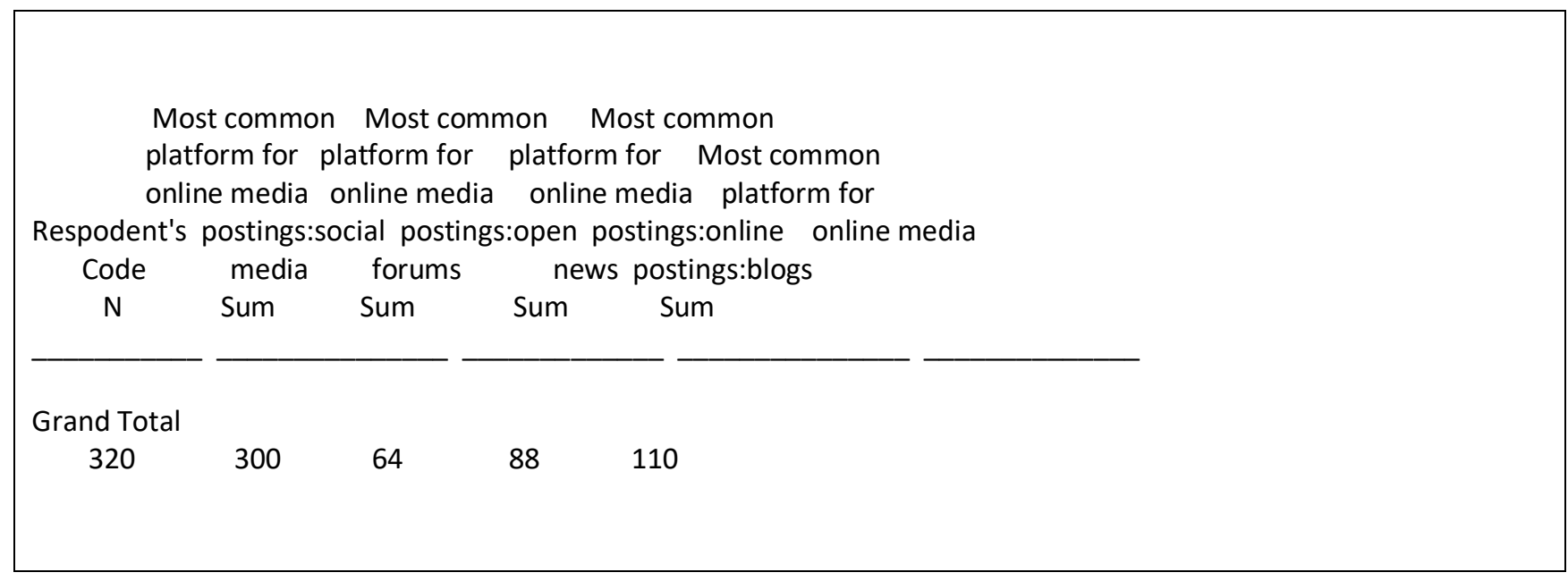

Table 4 reports the respondents' answer to survey, which online media platform where online shaming postings are commonly found. There are four types of media platform listed in the survey i.e. social media, open forums, online news and blogs. For this survey, the respondents are allowed to choose as many online social media as they like. An overwhelming number of respondents i.e. 300 $(93.75 \%)$ had chosen social media as the online media platform where online shaming postings are commonly found.

\section{RESULTS AND DISCUSSION}

There are four issues involving online shaming which have been surveyed in this study.

First issue is on the offences or anti-social behaviours that are commonly read, post, share, like or commented by the respondents through social media. The finding indicates that 8 out of 16 offences/anti-scoial behaviors are commonly read, post, share, like or commented by majority of the respondents.

Second issue is on the respondents' personal experience i) in making online shaming posting; ii) of being shamed online; iii) in giving like, sharing or commenting shaming posting. The finding indicates that majority of the respondents have neither made online shaming posting, nor being shamed online. While majority of the respondents have never been shamed, $30.3 \%$ of the respondents admitted tohave liked, share or commented shaming posting online. 
Third issue is on online social media application commonly associated with online shaming. The finding indicates that Whatsapp is the social media application commonly associated with online shaming, followed by youtube, facebook and twitter. The finding is consistent with the popularity of Whatsapp application among the Malaysian public compared to other social media such as telegram, which records the lowest number of response rate.

Fouth issue is on online media platform where online shaming postings are commonly found. Between four media platform listed in the survey, social media has been chosen as the online media platform where online shaming postings are commonly found ahead of other online platform such as open forums, online news and blogs. Again, this finding is consistent with the fact that social media is the most popular communication platform among Malaysian public.

All the findings above suggest the existence of the culture of online shaming in Malaysia. These findings are consistent with the writings made by Goldman (2015), Moukalled (2015), Schulten, (2015), Cheung (2012) and Skoric (2010) on the prevalent culture of online shaming. The findings also revealed the respondent's inclination to like, share or comment to online shaming postings on sensitive issues involving sexism, racism and religion. These are sensitive issues that are known capable of creating tension and social unrest amongst the multi-cultural and multi-religion society in Malaysia.

Based on the findings, it is hereby proposed for the institutions of higher learning and schools to conduct an awareness programme on the negative effects of online shaming culture be conducted amongst students. The awareness programme should emphasize on the legal implications of online shaming arising from section 114A of the Evidence Act 1950 (presumption of online publication), section 211 of the Malaysian Communications and Multimedia Act 1998 (prohibition of online publication of false, annoying and threatening materials), Sedition Act 1948, Official Secrets Act 1972 and Data Protection Act 2010.

The awareness campaign should also emphasize on the recently announced guideline by the Malaysian Ministry of Education on online shaming. Under the guideline, sharing and posting criticisms of government and school policies are now banned alongside cyber bullying covering both students and teachers. (Sarban Singh, 2017). The new guideline also lists sharing someone else's embarrassing photos and spreading rumours as cyber bullying. The guideline prohibits teachers and students from making or sharing any sensitive information related to political, religious and racial matters, especially if these could threaten national security.

Through this awareness campaign, it could educate the students in the universities and schools on the legal consequences of online shaming. This could help to curb the culture of online shaming from becoming more prevalent and rampant among Malaysian societies.

\section{CONCLUSION}

This study investigates the culture of online shaming in Malaysia, with UiTM law students have been selected as the population of survey. At the outset, the findings of the survey are consistent with international literature on online shaming. In hindsight, the findings of survey raised an alarm on the worrying state of the culture of online shaming in Malaysia. Being a country with high internet penetration rate $(87.5 \%)$ and smartphone ownership stood at $70 \%$ among its population, Malaysia is confronted by the negative culture of online shaming. Though the findings are limited to the number 
INTERNATIONAL JOURNAL OF ACADEMIC RESEARCH IN BUSINESS AND SOCIAL SCIENCES Vol. 8, No. 10, Oct. 2018, E-ISSN: 2222-6990 ㄷ 2018 HRMARS

of respondents surveyed, they provide an insight to the existence of the culture of online shaming in Malaysia generally. The recent introduction of a guideline on online shaming by the Ministry of Education applicable to teachers and students, serves as evidence that the culture of online shaming is prevalent and had produced negative effects in education institutions, and need to be curbed. To gain better insight into this infamous culture, this study proposed for a large-scale survey at national level to be conducted in the future.

\section{ACKNOWLEDGMENTS}

The research was supported by Universiti Teknologi MARA (UiTM). This paper is derived from the research titled The Efficacy of Online Shaming as A Modality for Social Control (2017). The authors thank UiTM for awarding the grant in carrying out the research with the project code 600-IRMI/DANA 5/3/LESTARI (0158/2016).

\section{REFERENCES}

Allen, S. (2014). Online Shaming Gives Creeps the Spotlight They Deserve. http://www.thedailybeast.com/articles/2014/09/23/online-shaming-fighting-back-in-the-internet$\underline{\text { age.html }}$

Carson, B. (2015). Monica Lewinsky: Stop the 'Blood Sport' of Shaming People Online. Retrieved from Business Insider Malaysia website: http://www.businessinsider.my/monica-lewinsky-stop-theblood-sport-of-shaming-people-online-2015 6/?r=us\&ir=t\#c36g1f0opdil5rbg.97

Cheung, Anne S. Y., Revisiting Privacy and Dignity: Online Shaming in the Global E-Village (February 24, 2012). University of Hong Kong Faculty of Law Research Paper No. 2012/19. Available at SSRN: https://ssrn.com/abstract=2010438 or http://dx.doi.org/10.2139/ssrn.2010438 doi: 10.3390/laws3020301

Dewey, C. (2015, 16 September). Can Online Shaming Shut Down the Internet's Most Skin-Crawly Creeps?, The Washington Post. Retrieved from https://www.washingtonpost.com/news/theintersect/wp/2015/09/16/can-online-shaming-shut-down-the-internets-most-skin-crawly-creeps/

Fagbenle, T. (2013). Online 'Shaming' A New Level of Cyber bullying for Girls. http://www.npr.org/2013/01/07/168812354/online-shaming-a-new-level-of-cyberbullying-for-girls Goldman, L. M. (2015). Trending Now: The Use of Social Media Websites in Public Shaming Punishments. American Criminal Law Review, 52.

Ho, A. (2015, 26 April). The Morality of Public Shaming, The Star. Retrieved from http://www.thestar.com.my/news/nation/2015/04/26/the-morality-of-public-shaming-given-thepopularity-of-social-media-if-you-offend-enough-people-expe/Nation

Kaplan. (2015). Facebook Shaming-turned-suicide isn't Just for Teenagers Anymore, https://www.haaretz.com/blogs/routine-emergencies/.premium-1.658145 
INTERNATIONAL JOURNAL OF ACADEMIC RESEARCH IN BUSINESS AND SOCIAL SCIENCES

Vol. 8, No. 10, Oct. 2018, E-ISSN: 2222-6990 ㄷ 2018 HRMARS

Klonick, K. (2015). Re-Shaming the Debate: Social Norms, Shame, and Regulation in an Internet Age. http://ssrn.com/abstract=2638693 or http://dx.doi.org/10.2139/ssrn.2638693 https://twedya.com/society/item/749-online-shaming-is-it-the-best-way-forward?action=print

Mann, S., Nolan, J., \& Wellman, B. (2003). Sousveillance: Inventing and Using Wearable Computing Devices for Data Collection in Surveillance Environments. Surveillance \& Society 1(3): 331-355, 1(3), 331-355.

Massaro, Toni M. (1991). Shame, culture, and American criminal law. Michigan Law Review 89(7): 1880-1944.

Moukalled, D. (2015). The Perils of Social Media's Public Shaming. http://english.alarabiya.net/en/views/news/middle-east/2015/08/05/The-perils-of-social-media-spublic-shaming.html

Nurulsyahirah, D. (2015). Not Between Her and Allah: Hijab Shaming in Malaysia. http://www. muslimahmediawatch.org/2015/10/06/not-between-her-and-allah-ijab-shaming-in-malaysia/.

Phillips, W., \& Miltner, K. (2012). The Internet's Vigilante Shame Army. http://www.theawl.com/2012/12/the-internets-vigilante-shame-army

Poole, Emily, (2013), Hey Girls, Did You Know: Slut-Shaming on the Internet Needs to Stop Comments and Notes, 48 U.S.F.L.Rev. (2), 221.

Sarban Singh. (17 August 2017). New guidelines to stem cyberbullying. The Star Online. Retrieved from http://www.thestar.com.my/news/nation.

Schulten, K. (2015, 26 March). Is Our Culture of Online Shaming Out of Control?, The New York Times. Retrieved from http://learning.blogs.nytimes.com/2015/03/26/is-our-culture-of-online-shamingout-of-control/?_r=0

Skoric, M. M., Wong, K. H., Chua, J. P. E., Yeo, P. J., \& Liew, M. A. (2010). Online Shaming in the Asian Context: Community Empowerment or Civic Vigilantism? Surveillance \& Society, 8(2), 181-199.

Wehmhoener, K. A. (2010). Social Norm or Social Harm: An Exploratory Study of Internet Vigilantism. (Master), lowa State University, Ames, lowa. Retrieved from http://lib.dr.iastate.edu/cgi/viewcontent.cgi?article=2561\&context=etd 